\title{
Spatial effects of container ports on production of the leather, bag and shoe industry in Korea
}

\author{
Yong An Park
}

Korea Maritime Institute, 26, Haeyang-ro 301, Yeongdo-gu, Busan, 606-080, Korea

Email: yapark@kmi.re.kr; ucesyap@ucl.ac.uk

\section{Francesca Romana Medda*}

UCL QASER Lab,

Faculty of Engineering, University College London, Chadwick Building, Gower Street London, WC1E 6BT, UK

Email: f.medda@ucl.ac.uk *Corresponding author

\begin{abstract}
Container port operations are widely regarded as being beneficial to regional economies, particularly in aggregated terms. The present paper examines this common knowledge in the specific case of the leather, bag and shoe industry in Korea. The authors use two panel datasets of the industry, one dataset of 16 regions and the other dataset of enduring establishments from 1991 to 2011. In our analysis with panel data of the regions, the authors find that an increase of container throughput in ports affects production of the industry positively during the examined period. When dividing the examined period into two periods, the authors observe the negative effects during the period before 2003 and primarily in the groups of regions without large ports. The panel data model of enduring establishments presents a negative coefficient of port throughput on production. The contradictory results may be caused by the characteristics of the two different panels.
\end{abstract}

Keywords: container port; panel data model; industry; regional effect; Korea.

Reference to this paper should be made as follows: Park, Y.A. and Medda, F.R. ( $x x x x)$ 'Spatial effects of container ports on production of the leather, bag and shoe industry in Korea', Int. J. Shipping and Transport Logistics, Vol. X, No. Y, pp.xxx-xxx.

Biographical notes: Yong An Park is a Research Fellow at the Korea Maritime Institute, Busan, Korea. He received his $\mathrm{PhD}$ in Economics from Kyung Hee University, Korea and currently a $\mathrm{PhD}$ candidate in Spatial Economics at the University College London (UCL), London, UK. His research areas include maritime services, intermodal transport, and interaction between transport and regional economy.

Francesca Romana Medda is a Professor of Applied Economics and Finance at the University College London (UCL), London, UK. Her research focuses on project finance, innovative financial mechanisms and risk evaluation in different infrastructure sectors such as: transport industry, energy innovation 
and new technologies, urban investments (smart cities), supply chain provision and optimisation, and efficiency.

This paper is a revised and expanded version of a paper entitled 'Spatial effects of container port on output of leather, bag and shoe industry in Korea' presented at GPRA Conference on Port and Logistics Connectivity, Hong Kong, 21-22 May 2015.

\section{Introduction}

Transport is the indisputable connector between production and supply activities. From the vantage point of industry and business, the location of a production plant and a business entity determines the extent to which they can realise profits and reduce costs. Scholars have verified that cheaper or better goods, materials, and intermediates for consumption and production can be found in an open and networking economy than in a closed and land-locked one (Gallup et al., 1999; MacKellar et al., 2000; Rodrigue and Notteboom, 2010).

In Korea, ports are the key transport infrastructures, handling nearly $100 \%$ (99.6\%) of foreign trade by volume (Ministry of Land, Transport and Maritime Affairs of Korea, 2009). The present paper selects the leather, bag and shoe industry since its shares of output in manufacturing in Busan declined dramatically from 22\% in 1991, top-rank in manufacturing industries in Busan to 5.6\% in 2011 (Statistics Korea, 1991-2011). In the late 1910s, at the outset of the shoe industry, Busan port introduced new technologies and raw materials from foreign countries, and continued to promote the industry's growth beyond the 1960s (Jeong, 2004; Shin, 2004; Kim et al., 2008). By the late 1980s, however, a number of Korean labour-intensive manufacturers of leather, bags and shoes, relocated their plants to other countries where labour costs were lower (Shin, 2004; Seo et al., 2015). Leather, bag and shoe production in Korea decreased its shares of employment, output, and value added in manufacturing industries, from $3.5 \%, 2 \%$, and $2.2 \%$ in 1991 to $1.2 \%, 1.2 \%$, and $0.9 \%$ in 2011 respectively (Statistics Korea, 19912011). The industry also witnessed a dynamic reversal in trade: from exporter in the 1990s to importer in 2003.

When deciding on investments for transport infrastructure, like ports or container terminals, the Korean government evaluates the regional effects of such development mainly through the use of Input-Output modelling, such as in the standard guidelines for pre-feasibility studies on ports (Kim, 2001), and general guidelines for pre-feasibility studies (Shim, 2004). The input-output model interprets the expansion and development of a port facility as an external additional input of industries. The model always yields positive production inducement effects; value added effects, and employment inducement effects, as illustrated in a Korean case (Kwak et al., 2005). As a result, policy makers only observe the combined positive results but not the concrete impacts of the port development on each industry. In the literature we notice that individual industries are analysed in exceptional cases. Using robust methods to evaluate actual regional effects of transport infrastructure development is important in the design of regional and port development policy. Furthermore, when an industry supplies major employment and production in a regional economy as in the case of the leather, bag and shoe industry in 
Busan in the early 1990s, a more precise evaluation of port development may provide policy improvements. In our view, it is therefore useful to test regional and spatial effects for a specific industry over long-term periods.

The present paper aims to evaluate the effects of container port activities on the output of leather, bag and shoe manufacturing, which has been in decline since the late 1980s. For this purpose, we gather three types of panel data on the industry surveyed by the Statistics Korea: the regional panel data on the industry, panel data on enduring establishments that have sustained their business activity from 1991 to 2011, and panel data on industrial complexes. Container throughput is introduced as an indicator of port activity from 1991 to 2011. Due to inconsistent data and insufficient case numbers in the panel data of industrial complexes, we apply a panel data model on the regional data and the enduring establishment data. We also examine whether generally positive effects of port development can be confirmed in the industry and discuss how regional impacts of a port occur in regions over different periods.

Our contribution to the literature has three sides. First, the paper reviews the regional effects of container ports on a specific manufacturing industry, which shows a decrease in comparative competitiveness in global trade. Controlling the changes of comparative competitiveness, the paper tries to examine precisely the effects of port development on a specific manufacturing sector. Second, the paper evaluates the effects not by aggregated and averaged variables, but by variables of each establishment of the manufacturing group. By using panel datasets of each business unit, the paper traces microscopically the effects of port development on the specific manufacturing sector. Third, while more studies may need to be done, this paper points to trends in specialisation and international division of production in accordance with transport development, which are asserted in the literature of economic geography. A microscopic investigation of the paper in longitudinal and cross-sectional cases provides a hint on phenomenon of specialisation and international division of production.

The paper is set out as follows. Section 2 reviews the literature on effects of transport infrastructure, specifically the development of ports and their impacts on regional economies. Section 3 describes the data and modelling. Data are composed of the statistics of regional output and input of leather, bag and shoe manufacturing. We examine the stationarity of panel data through a unit root test. In Section 4 we provide the results of our panel data model using two types of data: regional and enduring establishment data of the industry. Lastly, Section 5 discusses the policy implication of the results in views of the stakeholders in Korean container ports. The section also reiterates our findings and suggests the next steps for research in this area.

\section{Literature review}

A port has three main relationships with its hinterland and regional economies: transport networking, spatial interaction, and economic ties. Insofar as the effects of a port on regional economies and hinterland are concerned, we find in relation to port development that the function of a port has evolved from a simple node to a phase of regionalisation (Notteboom and Rodrigue, 2005). Regionalisation of a port suggests the formation of transport networks between a port and its hinterland. In addition, in spite of analyses on the spatial structure between a city and its port in Africa, Europe and Asia (Gleave, 1997; 
Ducruet and Jeong, 2005; Lee et al., 2008), we still must ask questions on how, why, and to what degree a port specifically affects each industry and each business unit.

Therefore, we intend to magnify our analysis in order to better understand the relationship between port development and its effect on specific industries. Papers on transport development generally emphasise the positive impacts of transport facilities in aggregated terms that can lower transport costs and improve accessibility (Gallup et al., 1999; Limao and Venables, 2001; Harringan and Venables, 2006; Behrens et al., 2009; Jiwittanakulpaisarn et al., 2010; Li and Li, 2013; Tong et al., 2013; Park and Seo, 2016). According to some of the economic geography literature, lower transport costs influence the production decisions of a firm as well as the spatial division of production (Krugman, 1980; Beckmann and Thisse, 1986; Behrens and Picard, 2011). Behrens and Picard (2011) assert that trade imbalances introduce asymmetric freight rates between inbound cargo and outbound cargo, and manufacturing firms may disperse economic activities from a larger country or market to a smaller country or market. Nevertheless, the literature on economic geography seldom investigates a firm's production decision when the transport network in a region changes.

Several studies of specific industries and firms verify that transport improvement promotes a 'destructive creation' through the movement of materials and energy (Foster et al., 2001; Pavcnik, 2002). Although Goss (1990) does not study in detail the effects of port development on specific manufacturers, he does suggest that the improvement of port efficiency can benefit both producer and consumer; he goes on to specialisation in some sectors and diversification in others (Goss, 1990). One study interpreting the role of a port in containerisation in the USA finds that ports may cause the economic decline in the port district (Grobar, 2008). As the global economy and regional industries evolve, some industries grow as others diminish and we can observe how port cities shift their manufacturing from developed to developing countries, and how, gradually, industrial clusters start to change and sometimes disappear.

Stevens et al. (1981) examine the regional effects of port development and point out the positive inducement effects in Massachusetts in the US. Cohen and Monaco (2008) conclude that port infrastructure contributes to the regional output of manufacturing in the US. In recent studies we can see different attempts to assess the regional effects of port development. Using regional and macro panel data of China from 2003 to 2010, Shan et al. (2014) find positive effects of a port (or container port) on the economic growth of Chinese regions. In the analysis on aggregated regional production function of Spain, Arbues el al. (2015) illustrate that only road development brings positive effects to regional production while the other transport modes do not show a clear impact on regional economy. Park and Seo (2016) aggregate the impact of seaports on the regional economies in Korea, adopting regional GDP including fishery and agriculture, manufacturing, and service activities. These papers use an aggregated concept of economic growth which, however, prevents them from investigating specific impacts of a port on each manufacturing industry, each establishment, and over different periods. Although Bottaso et al. $(2013,2014)$ analyse spillover effects of port throughput on the regional growth of a port city and other regions, they also neglect to test the impacts of a port at the industry and establishment levels. These aggregated approaches that almost always produce optimistic results are limited because they do not explain why a major port exists in the face of a shrinking city, along with the demise of specific manufacturing industries in that city and its hinterlands. 
In general, manufacturing industries evolve through different stages: emergence, growth, competition, and decline, similarly as in the vision of creative destruction by Schumpeter (Krafft et al., 2014). We suggest that insights can be gained from studying the effects of port on specific industries in different stages of their evolution and comparative competitiveness in global trade. For example, starting in the late 1980s, the leather, bag and shoe industry in Korea began moving its main plants to developing countries (e.g., Thailand and Indonesia), and closing some factories because competition was severe. However, the port of Busan developed into a hub port in the 1990s, largely due to an increase in transshipment containers from neighbouring countries, especially Japan and China (Chang, 2000). The Korean government, municipal governments, and port authorities in Korea tend to believe that port development brings positive effects to regional economies; therefore, they have tried to build larger port terminals and logistics facilities nearby ports in order to attract cargo from manufacturers and promote diverse industrial activities (Seo et al., 2015). In the next section we begin our assessment of the spatial effects of port throughput on the leather, bag and shoe industry.

\section{Model and data}

Although the input-output model has rigid and positive effects, it is used widely to verify the positive effects of port development on other industries (Kwak et al., 2005). In general, port development has average positive results; however a specific industry in a region may yield different outcomes. Starting from the vantage point that, in an open economy, transportation matters at decision level on the location of production and with regard to patterns of trade, Krugman (1990) and Behrens and Picard (2011) developed models in which a more even spatial distribution of firms and production occurs when freight rates are considered as endogenous. Krugman (1990) mainly considers market size and transportation costs for each country, and agglomeration in the region where economies of scale are better, whereas Behrens and Picard (2011) focus on the difference in transportation costs in accordance with trade direction, and the possibility of agglomeration in the smaller country due to lower transportation costs to export. In container transport and hub-and-spoke networks, a hub port in particular tends to build diverse and high frequency feeder networks with regional small and medium sized ports. Hence, it is questionable how development of a hub port affects a specific regional industry.

As a transport infrastructure, a container port may shift production function (Bottaso et al., 2014; Shan et al., 2014). Production function as illustrated in equation (1) includes the value of outputs of, e.g., leather, bag and shoe manufacturing establishments, and inputs: labour, capital, intermediates, and port activity indicators including such inputs as port throughput or handling capacity of a port.

$$
Y=f(l, k, i m, p t)
$$

$y \quad$ output of leather, bag and shoe industry

l labour input

$k$ capital input

im intermediates input 
pt port throughput.

Figure 1 Map of the 16 regions in Korea (see online version for colours)

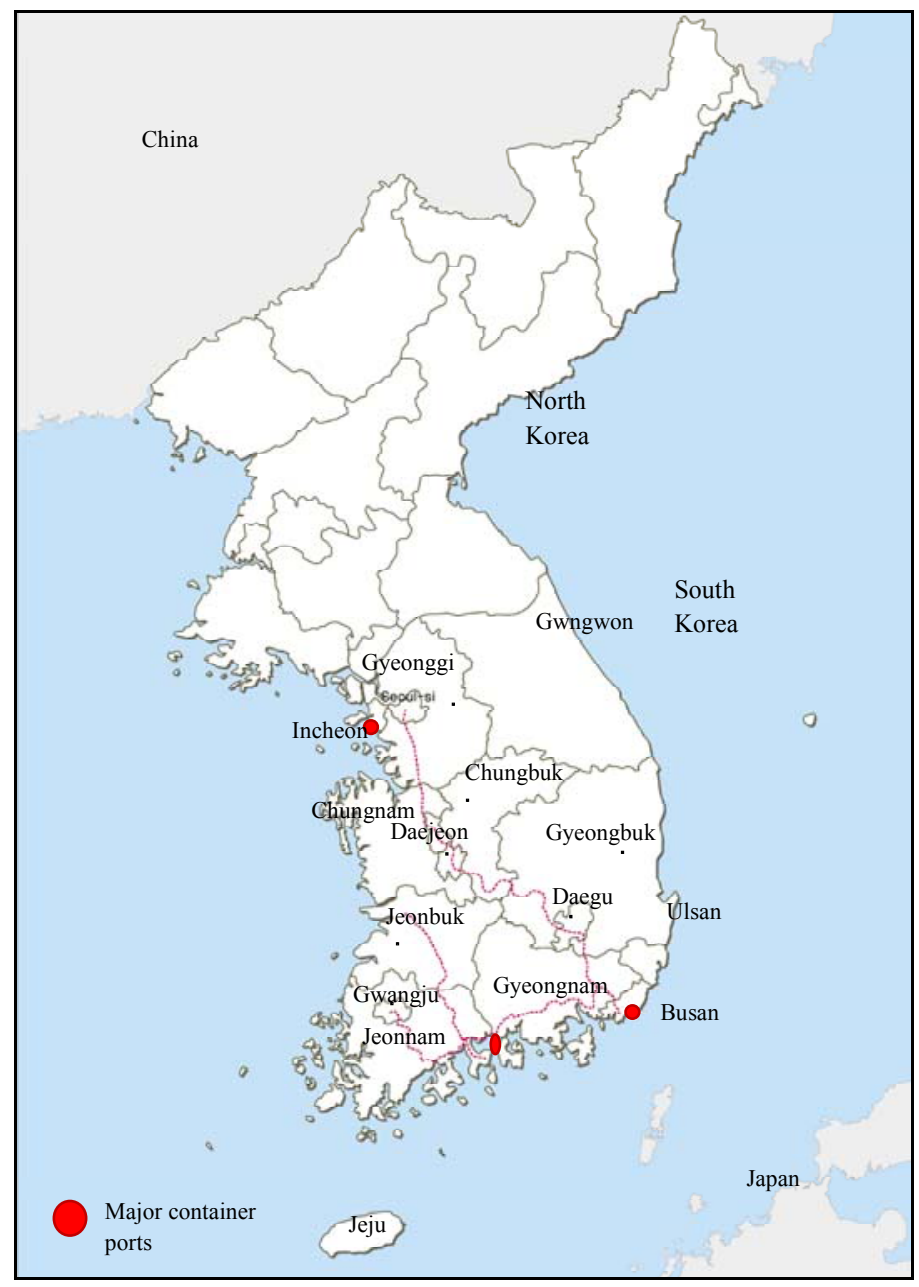

Firms in an open economy are exposed to competition from foreign competitors. A firm can also move its plants to foreign countries. Therefore, from the point of view of a country, its position in manufacturing and global trade can shift from production to consumption. The trade specialisation index (TSI) ranging from +1 to -1 specifies the position of export and import for manufacturers in a country (UNCTAD, 2013). Hence, we can trace the positioning of the Korean leather, bag and shoe industry by calculating the TSI. Another indicator, revealed comparative advantage (RCA) varying over 0 , informs us on the comparative competitiveness of each manufacturer for a country involved in global trade. We add the RCA index of the industry as a dummy variable in the production function to evaluate the comparative competitiveness of the industry in the world. The production function can now be written as in equation (2). 


$$
y=f(l, k, i m, p t, r c a)
$$

Regional outputs, as shown in Table 1, represent the output value of leather, bag and shoe manufacturing for the 16 administrative regions in Korea, listed in Figure 1. We use wages as a proxy for labour input. Value of capital input is calculated by multiplying the yield of private bonds and tangible assets. Intermediates are composed of raw materials, fuel, electricity, and other materials for production. In Table 1 port throughput indicates the container movement around the regional port where leather, bag and shoe manufacturers are located.

Table 1 Summary of panel data of the 16 regions

\begin{tabular}{lcccc}
\hline Item & Min & Max & Mean & $\begin{array}{c}\text { Standard } \\
\text { deviation }\end{array}$ \\
\hline Output (million Korean Won) & 0 & $2,839,696$ & 265,614 & 513,984 \\
Wages (million Korean Won) & 0 & 624,375 & 32,693 & 70,003 \\
Intermediates (million Korean Won) & 0 & $1,316,339$ & 133,635 & 273,427 \\
Tangible assets (million Korean Won) & 0 & 621,583 & 58,011 & 115,024 \\
Port throughput (thousand TEU) & 0 & 15,523 & 625 & 2,115 \\
\hline
\end{tabular}

Note: Some regions do not show the existence of the industry.

Source: Statistics Korea (1991-2011) and Ministry of Oceans and Fisheries of Korea (1991-2011)

Figure 2 Trend of output and employees of the leather, bag and shoe industry (see online version for colours)

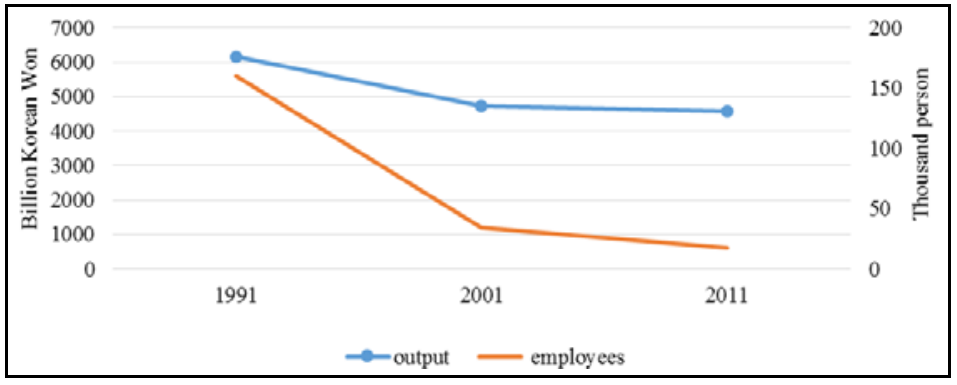

Source: Statistics Korea (1991-2011)

Total output and employees of the industry are shown in Figure 2. We can observe that total output drops from 6.1 trillion Korean Won in 1991 to 4.6 trillion Korean Won in 2011. We also observe in the figure that total employees plummet from 160,000 to 17,000. This sharp decrease occurs mainly in the Busan region, which had attracted shoe industry manufacturers since the 1960s. The output and employees of the industry in Busan falls from 2.8 trillion Korean Won and 100,000 employees in 1991 to 1.0 trillion Korean Won and 6,200 employees in 2011.

As a labour-intensive industry, leather, bag and shoe manufacturing was a main exporter in Korea during the 1970s. However, global demand for these products soon began spiralling downward; at the same time, other foreign producers in Asia were vigorously competitive during the 1980s. In Figure 3 the TSI of the industry of Korea 
indicates a change from an exporting to importing country around 2003, recording negative numbers for the first time: from 0.06 in 2002 to -0.04 in 2003 . Since 2002, the TSI depicts a steady downward slide in the industry's international competition. The RCA index also records continuous decrease in competitiveness of manufacturing in world trade, falling from 16.25 in 1991 to 0.11 in 2011.

Figure 3 TSI trend of the manufacturing for leather, bag and shoe (see online version for colours)

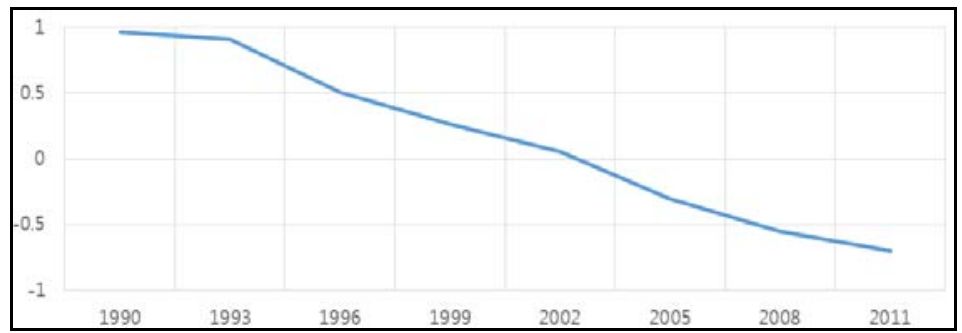

Note: TSI is calculated by weighted average of two industries in HS code of 42 (leather or of animal gut, harness, travel goods, handbags) and 64 (footwear, headgear, umbrella, walking sticks, whips, riding crops).

Source: Authors' elaboration on the data of UN Comtrade (1991-2011) and Korea International Trade Association (1990-2011)

The second dataset of enduring establishments in the industry gives us detailed statistics of each same business unit from 1991 to 2011. Though these establishments also show continual decrease in employment, 33 establishments could sustain their production during the period.

We find that the data on port development, mainly container throughput, are calculated in 20-foot equivalent units (TEU). We also assume that the impact of port expansion and change of competitive positioning of the industry occurs gradually. Hence, we use moving averages of port throughput and RCA in $t$ year and $t-1$ year as in the following similar method of the World Economic Forum (2010).

$$
\begin{aligned}
& m p t=0.6 p t_{t}+0.4 p t_{t-1} \\
& m r c a=0.6 r c a_{t}+0.4 r c a_{t-1}
\end{aligned}
$$

We test the stationarity of panel data of 16 regions through Levin-Lin-Chu unit-root test (LLC) and Fisher-type unit-root test based on augmented Dickey-Fuller tests (Fisher-ADF). Since at the level data we find unit root in port throughput and RCA, as shown in Table 2, we adopt the difference formation of each variable in a panel regression.

The data of difference formations show the improvement in stationarity of port throughput and RCA. Hence, we use mainly the data of difference formation in empirical models as in equation (5).

$$
Y=a 1+a 2 L+a 3 K+a 4 I M+a 5 M P T+a 6 M R C A+e
$$

$Y, L, K, I M, M P T$, and MRCA represent differences of variables of output, labour input, capital input, intermediates, moving average of port throughput, and moving average of $\mathrm{RCA}$ in $\mathrm{t}$ year. Equation (5) includes error term e. 
Table 2 Test of panel unit root

\begin{tabular}{|c|c|c|c|c|}
\hline \multirow{3}{*}{ Items } & \multicolumn{4}{|c|}{$p$ value } \\
\hline & \multicolumn{2}{|c|}{ Level data } & \multicolumn{2}{|c|}{ Difference formation data } \\
\hline & $L L C$ & Fisher-ADF & $L L C$ & Fisher-ADF \\
\hline Output & 0.0002 & 0.000 & 0.254 & 0.000 \\
\hline Wages & 0.002 & 0.000 & 0.002 & 0.000 \\
\hline Capital & 0.000 & 0.000 & 0.000 & 0.000 \\
\hline Intermediates & 0.000 & 0.002 & 0.001 & 0.000 \\
\hline Port throughput & 1.000 & 1.000 & 0.999 & 0.000 \\
\hline Revealed comparative advantage & 1.000 & 0.000 & 0.000 & 0.000 \\
\hline
\end{tabular}

Note: $\mathrm{p}$ value at LLC indicates the value of adjusted $t^{*} ; \mathrm{p}$ value at Fisher-ADF represents the value of inverse chi-squared.

The panel data include the period from 1991 to 2011, and we divide this long period into two: the first from 1991 to 2002, and the second from 2003 to 2011. Lastly, to sum up this section, we can indeed confirm from Figure 2, that around year 2003 the TSI of the industry shifts from positive to negative. For complementing the panel data model, the present paper adds the main result of a spatial econometric model in the next section.

\section{Panel data model and results}

In panel data model, we first test fixed effects model. Since the error term in the fixed effects model does not show the particularity of each panel as shown in Table 3, we adopt and examine the generalised least squares (GLS) estimator. We conduct a significance test of heteroscedasticity covariance of error term in a GLS estimator, and autocorrelation of the regional panel data, and contemporaneous correlation between regional panels in order to find suitable models (Greene, 2008; Adkins and Hill, 2011). Main results are shown in Table 3.

Table 3 Summary of suitability tests for models

\begin{tabular}{lc}
\hline Test & Results \\
\hline Characteristics of error term in fixed effects model & $\mathrm{F}(5,283)=0.45 ;$ Prob. $>\mathrm{F}=0.964$ \\
Test of heteroscedasticity covariance of error term & $\chi^{2}(15)=30,913 ;$ Prob. $>\chi^{2}: 0.000$ \\
Test of autocorrelation of panel in GLS & $\mathrm{F}(1,4)=1.1 ;$ Prob. $>\mathrm{F}=0.309$ \\
\hline
\end{tabular}

Note: Prob. means probability.

Source: Statistics Korea (1991-2011), Ministry of Oceans and Fisheries of Korea (1991-2011) and authors' elaboration

We do not find heterogeneity of each panel in the fixed effects model and homoscedasticity covariance of error terms in the GLS estimator, as in Table 3, so we will mainly adopt panel GLS estimators. In the panel GLS we select various models of different types: GLS estimator in heteroskedastic error term with cross-sectional correlation (GLS panel corr), GLS estimator, GLS estimator with panel heteroskedastic error term (GLS panel hetero), and GLS estimator with first-order autocorrelation [GLS panel AR (1)]. 
Table 4 Panel data model results at the regional panel

\begin{tabular}{|c|c|c|c|c|c|c|c|}
\hline \multirow{2}{*}{ Item/Model } & \multicolumn{3}{|c|}{ GLS panel corr } & \multirow{2}{*}{$\begin{array}{l}\text { GLS } \\
M 4\end{array}$} & \multirow{2}{*}{$\begin{array}{c}\begin{array}{c}G L S \\
\text { panel } \\
\text { hetero }\end{array} \\
\text { M5 }\end{array}$} & \multirow{2}{*}{$\begin{array}{c}\text { GLS } \\
\text { panel } \\
\text { AR(1) }\end{array}$} & \multirow{2}{*}{$\begin{array}{c}\begin{array}{c}\text { Fixed } \\
\text { effects }\end{array} \\
M 7\end{array}$} \\
\hline & M 1 & M 2 & M 3 & & & & \\
\hline Period & $\begin{array}{l}1992- \\
2010\end{array}$ & $\begin{array}{l}1992- \\
2002\end{array}$ & $\begin{array}{l}2003- \\
2010\end{array}$ & $\begin{array}{l}1992- \\
2010\end{array}$ & $\begin{array}{l}1992- \\
2010\end{array}$ & $\begin{array}{c}1992- \\
2010\end{array}$ & $\begin{array}{l}1992- \\
2010\end{array}$ \\
\hline Constant & 1,797 & 2,342 & 2,739 & 2,931 & $1.3 \mathrm{e}-15$ & 2,738 & 4,695 \\
\hline Wages & $\begin{array}{c}2.65 * * * \\
(53.6)\end{array}$ & $\begin{array}{c}2.42 * * * \\
(27.72)\end{array}$ & $\begin{array}{c}3.13 * * * \\
(19.22)\end{array}$ & $\begin{array}{c}2.73 * * * \\
(9.78)\end{array}$ & $\begin{array}{c}1.98 * * * \\
(6 \mathrm{e}+9)\end{array}$ & $\begin{array}{c}2.46 * * * \\
(12.33)\end{array}$ & $\begin{array}{c}2.87 * * * \\
(9.67)\end{array}$ \\
\hline Capital & $\begin{array}{c}0.20 \\
(1.05)\end{array}$ & $\begin{array}{c}0.01 \\
(0.07)\end{array}$ & $\begin{array}{c}5.64 * * * \\
(4.54)\end{array}$ & $\begin{array}{c}0.14 \\
(0.16)\end{array}$ & - & $\begin{array}{c}0.84 \\
(-1.26)\end{array}$ & $\begin{array}{c}0.41 \\
(0.47)\end{array}$ \\
\hline Intermediates & $\begin{array}{l}1.37 * * * \\
(97.41)\end{array}$ & $\begin{array}{l}1.02 * * * \\
(73.03)\end{array}$ & $\begin{array}{l}1.21 * * * \\
(19.22)\end{array}$ & $\begin{array}{l}1.37 * * * \\
(23.02)\end{array}$ & - & $\begin{array}{l}1.39 * * * \\
(32.52)\end{array}$ & $\begin{array}{l}1.35 * * * \\
(21.87)\end{array}$ \\
\hline $\begin{array}{l}\text { Port } \\
\text { throughput }\end{array}$ & $\begin{array}{c}5.23 * * * \\
(6.08)\end{array}$ & $\begin{array}{c}-8.63 * * \\
(-2.48)\end{array}$ & $\begin{array}{c}8.50 * * * \\
(3.34)\end{array}$ & $\begin{array}{c}9.49 \\
(0.73)\end{array}$ & $2.1 \mathrm{e}-15$ & $\begin{array}{c}3.47 \\
(0.32)\end{array}$ & $\begin{array}{l}-15.61 \\
(-0.78)\end{array}$ \\
\hline $\begin{array}{l}\text { Revealed } \\
\text { comparative } \\
\text { advantage }\end{array}$ & $\begin{array}{l}-264 \\
(-1.44)\end{array}$ & $\begin{array}{c}1,199 * * * \\
(6.27)\end{array}$ & $\begin{array}{c}-22,746 \\
(-0.58)\end{array}$ & $\begin{array}{l}-65 \\
(0.73)\end{array}$ & $3.6 \mathrm{e}-15$ & $\begin{array}{l}1,766 \\
(1.02)\end{array}$ & $\begin{array}{c}-94 \\
(-0.04)\end{array}$ \\
\hline Sample size & 304 & 160 & 144 & 304 & 304 & 304 & 304 \\
\hline$\chi^{2}$ & 31,330 & 19,380 & 7,334 & 2,045 & $3.8 \mathrm{e}+19$ & 2,906 & F: 379 \\
\hline $\begin{array}{l}\text { Probability > } \\
\chi^{2}\end{array}$ & 0.0000 & 0.0000 & 0.0000 & 0.0000 & 0.0000 & 0.0000 & $\begin{array}{l}\text { Probability } \\
\text { > F: } 0.0000\end{array}$ \\
\hline
\end{tabular}

Notes: *significant at $10 \%$ level; **significant at $5 \%$ percent level; ***significant at $1 \%$ level. The figures in parenthesis mean $t$ value at fixed effects models.

Source: Statistics Korea (1991-2011) and author's elaboration based on the data

Table 4 gives the result of panel data model with regional panel datasets of difference formation. Model 1 GLS estimator in heteroskedastic error term with cross-sectional correlation (GLS panel corr), presents positive effects of port throughput on production of the industry from 1992 to 2010. After dividing this period into two, we obtain a contradicting result of signs in the effects of container throughput. Model 2, during the period from 1992 to 2002, indicates negative coefficient of container throughput on production; Model 3, positive coefficient from 2003 to 2010. When inputting total container throughput of Korean ports in place of container throughput of regional ports, we observe a negative coefficient of port throughput on production only during the period from 1992 to 2002 . The TSI shows continual decrease during the first period, signalling the positioning change in trade from production to consumption and from export to import in the global economy. In the second period, TSI confirms that the ratio of imports from foreign countries in the leather, bag and shoe industry grows incessantly. The negative effect of container throughput on production in model 2 implies a breakdown of the existing industry cluster. Although the paper does not describe in detail the results of spatial econometric models, the spatial econometric model also confirms a negative effect of port throughput on production from 1992 to 2002 as shown in Table 5 which presents direct and total effects. The remaining models $4,5,6$, and 7 , show us inconclusive effects 
of port throughput on production of the considered sectors. Model 5, GLS estimator with panel heteroskedastic error term (GLS panel hetero), does not present coefficients of capital and intermediate inputs.

Table 5 Direct and indirect effects of independent variables in spatial econometric model

\begin{tabular}{lccccc}
\hline Item/variables & Wages & Capital & Intermediates & $\begin{array}{c}\text { Port } \\
\text { throughput }\end{array}$ & $\begin{array}{c}\text { Revealed } \\
\text { comparative } \\
\text { advantage }\end{array}$ \\
\hline Direct effect & $2.36^{* * *}$ & $1.40^{* *}$ & $0.86^{* * *}$ & $-134.6^{* * * *}$ & $3.5 \mathrm{e}-10$ \\
Indirect effect & -0.07 & -0.04 & -0.03 & 4.3 & $-1.34 \mathrm{e}-10$ \\
Total & $2.3^{* * *}$ & $1.36^{* *}$ & $0.84^{* * *}$ & $-130.3^{* * *}$ & $2.2 \mathrm{e}-10$ \\
\hline
\end{tabular}

Source: Statistics Korea (1991-2002) and author's elaboration based on the data

Table 6 Panel data model results for two groups of regions

\begin{tabular}{|c|c|c|c|c|c|}
\hline \multirow{2}{*}{ Item $/$ model } & \multicolumn{5}{|c|}{ GLS panel correlation } \\
\hline & M 8 & M9 & M 10 & M 11 & M 12 \\
\hline Period & $1992-2010$ & 1993-2002 & $1992-2010$ & 1993-2002 & 2003-2011 \\
\hline \multirow[t]{2}{*}{ Region } & BS, IN & BS, IN & Except & Except & Except \\
\hline & & & BS, IN & BS, IN & BS, IN \\
\hline Constant & $-3,390$ & 2,007 & 3,404 & 3,286 & 4,612 \\
\hline \multirow[t]{2}{*}{ Wages } & $3.11 * * *$ & $3.57 * * *$ & $4.81 * * *$ & $3.84 * * *$ & $5.24 * * *$ \\
\hline & $(5.37)$ & $(5.13)$ & $(45.64)$ & $(25.24)$ & $(59.28)$ \\
\hline \multirow[t]{2}{*}{ Capital } & $-2.56^{*}$ & -2.67 & $3.82 * * *$ & $1.55 * * *$ & $4 / 49 * * *$ \\
\hline & $(-1.71)$ & $(-1.64)$ & $(8.70)$ & (3.98) & $(5.75)$ \\
\hline \multirow[t]{2}{*}{ Intermediates } & $1.07 * * *$ & $0.53 *$ & $1.15^{* * *}$ & $1.02 * * *$ & $1.12 * * *$ \\
\hline & $(7.34)$ & $(1.73)$ & $(31.10)$ & $(53.19)$ & $(30.72)$ \\
\hline \multirow[t]{2}{*}{ Port throughput } & -11.26 & -57.70 & $-5.89 * * *$ & $-17.53 * * *$ & 0.19 \\
\hline & $(0.72)$ & $(-1.15)$ & $(-4.09)$ & $(-5.48)$ & $(0.03)$ \\
\hline $\begin{array}{l}\text { Revealed comparative } \\
\text { advantage }\end{array}$ & $\begin{array}{l}-4,404 \\
(-0.55)\end{array}$ & $\begin{array}{l}6,936 \\
(0.66)\end{array}$ & $\begin{array}{c}1,048^{* * *} \\
(2.39)\end{array}$ & $\begin{array}{c}1,854 * * * \\
(9.41)\end{array}$ & $\begin{array}{c}-51,897 * * * \\
(-6.54)\end{array}$ \\
\hline Sample size & 38 & 20 & 266 & 140 & 126 \\
\hline$\chi^{2}$ & 711 & 211 & 716,155 & 11,157 & 20,346 \\
\hline Probability $>\chi^{2}$ & 0.0000 & 0.0000 & 0.0000 & 0.0000 & 0.0000 \\
\hline
\end{tabular}

Notes: *significant at $10 \%$ level; **significant at $5 \%$ level; ***significant at $1 \%$ level. Figures in parenthesis are $\mathrm{t}$ values.

Source: Statistics Korea (1991-2011) and author's elaboration based on the data

Using the econometric model of model 1 in the nation-wide analysis, as shown in Table 4, we can divide the country into two groups of regions as listed in Table 6: a group of regions with large port, Busan (BS) and Incheon (IC), and the other group of regions except Busan and Incheon. In the group of the large port, we do not find clear effects of port throughput on production in model 8 encompassing the whole period; and model 9 in the period from 1993 to 2002 . In the other region without a large port, we 
obtain a negative coefficient of port throughput on production in model 10 from 1992 to 2010, and a negative effect of port throughput in model 11 during the period from 1993 to 2002. While model 10 and model 11 present negative coefficients of port throughput, model 12 does not demonstrate a clear effect of port throughput. Regression results show that the group of regions without large port mainly experience negative effects of port throughput on production in the 1990s and the early 2000s. After adding Gyeonggi region where Pyungtaek port locates into the group with large port, we get similar results. The group of regions without large port in the panel data mainly experience negative effects of port throughput in the 1990s and the early 2000 s.

The Herfindahl Hirschman index (HHI) informs us about the degree of concentration of an economy. HHI of output of the considered industrial sectors shows very little change from 0.30 in 1991 to 0.28 in 2011, as illustrated in Figure 4: HHI of employment illustrates a decrease from 0.44 to 0.28 . At regional level, we can see a shift of main sources of output and employment from Busan to Gyeonggi region near Seoul, the capital city of Korea.

Figure $4 \mathrm{HHI}$ and shares of output and employment in Busan and Gyeonggi region (see online version for colours)

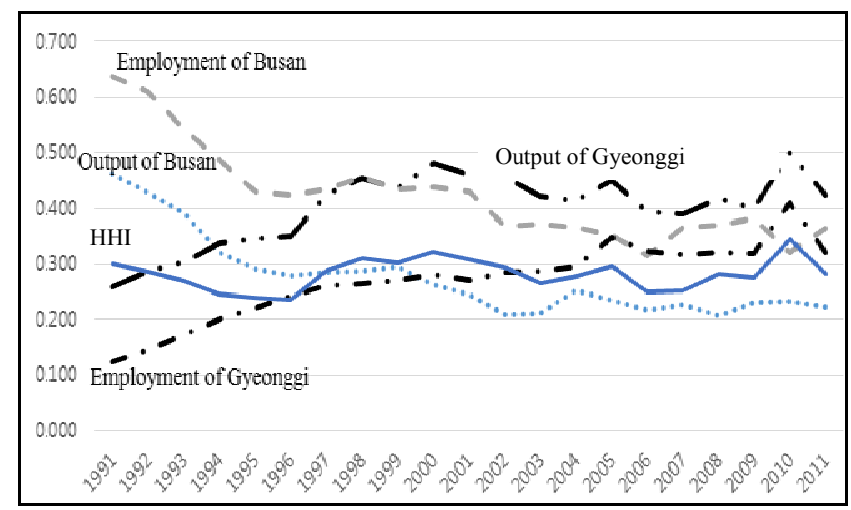

Source: Statistics Korea (1991-2011) and author's elaboration based on the data

Busan did accumulate the growth potential, partly due to geographical location as a port city until the early 1990s (Shin, 2004). However, it shows a decrease of shares in output and employment in the industry from 1991 to 2011 as shown in Figure 4: output fell from 0.46 to 0.22 ; employment dropped from 0.64 to 0.36 . In addition, the effects of container port in Busan on the industry are not clear in the panel regression as shown in Table 6. Hence, these imply that a decrease of shares of Busan in output and employment from 1991 to 2011 was not caused directly by port development but by other factors such as relatively higher labour costs. 
Spatial effects of container ports

Table 7 Number and average age of establishments in Busan and Gyeonggi region

\begin{tabular}{|c|c|c|c|c|c|c|}
\hline \multirow{2}{*}{ Item } & \multicolumn{2}{|c|}{1991} & \multicolumn{2}{|c|}{2002} & \multicolumn{2}{|c|}{2011} \\
\hline & Busan & Gyeonggi & Busan & Gyeonggi & Busan & Gyeonggi \\
\hline Number & 769 & 410 & 415 & 237 & 238 & 194 \\
\hline Average age (year) & 4.34 & 5.21 & 6.08 & 8.69 & 8.54 & 11.30 \\
\hline
\end{tabular}

Source: Statistics Korea (1991-2011) and author's elaboration based on the data

Table 8 Panel data model results of enduring establishments

\begin{tabular}{|c|c|c|c|c|c|c|c|}
\hline \multirow{2}{*}{ Item/model } & \multicolumn{3}{|c|}{ GLS panel correlation } & \multirow{2}{*}{$\begin{array}{c}\text { GLS } \\
M 16\end{array}$} & \multirow{2}{*}{$\begin{array}{c}\begin{array}{c}G L S \\
\text { panel } \\
\text { hetero }\end{array} \\
\text { M } 17\end{array}$} & \multirow{2}{*}{$\begin{array}{c}\text { GLS } \\
\text { panel } \\
\text { AR(1) } \\
M 18\end{array}$} & \multirow{2}{*}{$\begin{array}{c}\text { Fixed effects } \\
\text { M } 19\end{array}$} \\
\hline & M 13 & M 14 & M 15 & & & & \\
\hline Period & $\begin{array}{l}1992- \\
2010\end{array}$ & $\begin{array}{c}1992- \\
2002\end{array}$ & $\begin{array}{l}2003- \\
2010\end{array}$ & $\begin{array}{c}1992- \\
2010\end{array}$ & $\begin{array}{l}1992- \\
2010\end{array}$ & $\begin{array}{c}1992- \\
2010\end{array}$ & $\begin{array}{c}1992- \\
2010\end{array}$ \\
\hline Constant & 558 & 1,048 & -570 & 667 & 14 & 627 & 627 \\
\hline Wages & $\begin{array}{c}0.97 * * * \\
(6.56)\end{array}$ & $\begin{array}{c}1.59 * * * \\
(4.74)\end{array}$ & $\begin{array}{c}1.43 * * * \\
(3.10)\end{array}$ & $\begin{array}{c}0.83 * * \\
(2.29)\end{array}$ & $\begin{array}{l}1.20 * * * \\
(12.20)\end{array}$ & $\begin{array}{c}0.94 * * * \\
(2.61)\end{array}$ & $\begin{array}{l}0.69 * \\
(1.85)\end{array}$ \\
\hline Capital & $\begin{array}{c}2.55 * * * \\
(6.40)\end{array}$ & $\begin{array}{c}4.67 * * * \\
(9.04)\end{array}$ & $\begin{array}{c}5.40 * * * \\
(3.43)\end{array}$ & $\begin{array}{c}3.76 * * * \\
(4.45)\end{array}$ & $\begin{array}{c}0.29 * * * \\
(0.61)\end{array}$ & $\begin{array}{c}3.64 * * * \\
(4.34)\end{array}$ & $\begin{array}{c}3.78 * * * \\
(4.35)\end{array}$ \\
\hline Intermediates & $\begin{array}{c}0.59 * * * \\
(23.38)\end{array}$ & $\begin{array}{c}0.35^{* * *} \\
(6.86)\end{array}$ & $\begin{array}{c}0.64 * * * \\
(9.46)\end{array}$ & $\begin{array}{c}0.49 * * * \\
(13.09)\end{array}$ & $\begin{array}{l}1.16 * * * \\
(43.79)\end{array}$ & $\begin{array}{c}0.48 * * * \\
(13.08)\end{array}$ & $\begin{array}{c}0.48 * * * \\
(12.60)\end{array}$ \\
\hline $\begin{array}{l}\text { Port } \\
\text { throughput }\end{array}$ & $\begin{array}{c}-0.18 * * * \\
(-2.69)\end{array}$ & $\begin{array}{c}1.11 \\
(1.15)\end{array}$ & $\begin{array}{c}0.34 \\
(0.71)\end{array}$ & $\begin{array}{l}-0.35 \\
(-0.61)\end{array}$ & $\begin{array}{l}-0.03 \\
(-1.18)\end{array}$ & $\begin{array}{l}-0.53 \\
(-0.92)\end{array}$ & $\begin{array}{l}-0.19 \\
(-0.26)\end{array}$ \\
\hline $\begin{array}{l}\text { Revealed } \\
\text { comparative } \\
\text { advantage }\end{array}$ & $\begin{array}{c}258 * * * \\
(5.68)\end{array}$ & $\begin{array}{l}489 * * * \\
(2.71)\end{array}$ & $\begin{array}{l}-4,709 \\
(-0.53)\end{array}$ & $\begin{array}{c}254 \\
(1.06)\end{array}$ & $\begin{array}{l}-4.74 \\
(0.58)\end{array}$ & $\begin{array}{c}318 \\
(1.29)\end{array}$ & $\begin{array}{c}247 \\
(1.01)\end{array}$ \\
\hline Sample size & 703 & 370 & 333 & 703 & 703 & 703 & 703 \\
\hline$\chi^{2}$ & 805 & 178 & 129 & 208 & 2806 & 209 & F: 38 \\
\hline $\begin{array}{l}\text { Probability > } \\
\chi^{2}\end{array}$ & 0.0000 & 0.0000 & 0.0000 & 0.0000 & 0.0000 & 0.0000 & $\begin{array}{c}\text { Probability > } \\
\text { F: } 0.0000\end{array}$ \\
\hline
\end{tabular}

Notes: * significant at $10 \%$ level; ** significant at $5 \%$ level; *** significant at $1 \%$ level. The figures in parenthesis mean $t$ value at fixed effects models and $\mathrm{z}$ value at random effects model.

Source: Statistics Korea (1991-2011) and author's elaboration based on the data.

Gyeonggi region near the Seoul Metropolitan Area, embraces a few representative factories of leather bag and shoe makers in Korea such Esquire and Kumkang which are selling their outputs mainly in domestic markets. Shoe makers, including these two representative makers, led the employment, output and value added in the leather, bag and shoe industry since the mid of 1990s (Kim et al., 2008). Although the Busan region shows a continual decrease of shares in accordance with the positioning changes of the industry and the Gyeonggi region demonstrates a concentration of output and employment in proportion to the growth of imports, the effects of a container port on 
production of the industry is not clear for the group of regions with a large port. The average age of establishments in Gyeonggi shows lengthier longevity of establishments in the region than that of Busan: the average age in Gyeonggi extended from 5.21 year in 1991 to 11.30 year in 2011; Busan from 4.34 year to 8.54 year as illustrated in Table 7 . This means that the manufactures near the largest domestic market shows a higher possibility of survival even with the influx of imports.

The enduring establishments had been active in production from 1991 to 2011. In the unit root test and test of model suitability for panel of enduring establishments, we obtain a similar result. We test the effects of port throughput on production of the industry from the panel data of enduring establishments. Although model 13 in Table 8 presents a negative coefficient of port throughput on production, model 14 and model 15 do not show a clear coefficient of port throughput. We cannot find clear effects of port throughput on production in models $16,17,18$, and 19 of fixed effects model.

In the enduring establishment panel of Table 8 we obtain contradictory results for the regional panel, which shows positive effects from 1992 to 2010 but negative ones from 1992 to 2002. This may be caused by the characteristics of the two different panels: the regional panel includes diverse establishments; the enduring establishment panel contains only competitive establishments that have kept producing from 1991 to 2011, despite the fact that TSI and RCA have verified lower competitiveness in the considered industrial sector.

\section{Conclusions}

This paper has evaluated the effects of port throughput in Korea on the output of the leather, bag and shoe industry from 1991 to 2011. The industry in Korea experienced severe competition with foreign competitors in developing countries in Asia, and diminished its production capacity and employment since the late 1980s. Starting as an exporter, the leather, bag and shoe industry fairly rapidly turned into an importer by 2003. In the port business, the port of Busan evolved into a hub in North-East Asia in the early 1990s. With regard to the leather, bag and shoe industry, we have tested how port development impacts on an industry that underwent rapid change in the global economy. For this purpose, we used two panel datasets pertaining to the leather, bag and shoe industry from 1991 to 2011: regional panel data and panel data of enduring establishments.

We found in the regional panel data models that an increase of throughput in Korean ports positively affects the output of the industry from 1992 to 2010. The implication here is that Korean ports played a positive role in the development of the leather, bag and shoe industry and the business clustering. Second, if we divide the examined period into two, an increase of port throughput negatively affected the output from 1992 to 2002 and positively from 2003 to 2010 . The negative effects of increase of port throughput imply disaggregation of existing clusters in proportion to a decreasing ratio of exports. Third, the positive effects of port throughput in the regional panel from 2003 to 2010 signals that the effects of a container port work in both directions of cargoes: inbound and outbound. Fourth, we find negative effects in the group of regions without larger port, both in the whole period and in the period from 1992 to 2002. Therefore, the regions are affected negatively as the industry transformed from exporting to importing industry. Fifth, the negative effects of port throughput in the enduring panel datasets, from 1992 to 
2010, implies that the enduring establishments experienced negative effects in accordance with growing import.

The main results of the paper suggest some implications for policy makers. First, it is necessary for policy makers to assess separately the effects of port development on leading regional manufacturing. Although the aggregated regional effects present policy makers an indicator of feasibility, some manufacturing industries may be exposed more broadly to foreign competitors and shift their plants from the region to foreign countries. In the Korean Government, eagerness to develop transport hubs may have overlooked the potential harms caused to local manufacturing infrastructures. Second, the role of ports, especially container ports, is affected by changes of manufacturing in global trade. Although Busan port, as the main hub port in Korea, played a gateway for exports of the industries till the early 2000s, Incheon port has increased its importance in handling imports since the early 2000s. Hence, a balanced policy on port development between Busan port and Incheon port could reduce the logistics costs of shippers. Third, different aspects of regional effects of container ports signal stakeholders to respond optimally to changes of manufacturing industries in proportion to port expansion. A region embracing manufacturers with decreasing comparative competitiveness in global trade may face diminishing manufacturing both from decreasing exports and an increasing influx of goods, particularly if the region does not have a hub container port.

This paper represents our attempt to shed light on the regional effects of port development on manufacturing in Korea. However, the analysis has a number of limitations. Firstly, detailed responses from manufacturers about the impacts of port development on individual establishments of the leather, bag and shoe industry would add useful information to the present study. Secondly, a comparison with other types of industries could provide deeper insights into the relationship between port development and manufacturing. Thirdly, we think that spatial weight of transport costs and spatial weight panel regression studies should also be carried out. And fourthly, the present paper would have benefitted from using panel data of freight rates of container shipping routes by identifying which factors influence the direction of trade in the global market, as studied by Krugman (1990) and Behrens and Picard (2011).

\section{Acknowledgements}

The authors appreciate the anonymous reviewers and Dr. Dong-Woo Ha for their very valuable comments and suggestions on this article.

\section{References}

Adkins, L.C. and Hill, R.C. (2011) Using STATA for Principles of Econometrics, pp.442-483, John Wiley \& Sons, Inc., New York.

Arbues, P., Banos, J.F. and Mayor, M. (2015) 'The spatial productivity of transportation infrastructure', Transportation Research Part A, Vol. 75, pp.116-177.

Beckmann, M.J. and Thisse, J.F. (1986) 'The location of product activities', in Nijkamp, P. (Ed.): Handbook of Regional and Urban Economics, Vol. 1, pp.21-95, North-Holland, Amsterdam.

Behrens, K. and Picard, P.M. (2011) 'Transportation, freight rates, and economic geography', Journal of International Economics, Vol. 85, No. 2, pp.280-291. 
Behrens, K., Gaigne, C. and Thisse, J.F. (2009) 'Industry location and welfare when transport costs are endogenous', Journal of Urban Economics, Vol. 65, No. 2, pp.195-208.

Bottaso, A., Conti, M., Ferrari, C. and Tei, A. (2014) 'Ports and regional development: a spatial analysis on a panel of European regions', Transportation Research A, Vol. 65, pp.44-55.

Bottaso, A., Conti, M., Ferrari, C., Merk, O. and Tei, A. (2013) 'The impact of port throughput on local employment: evidence from a panel of European regimes', Transport Policy, Vol. 27, pp.32-38.

Chang, S.E. (2000) 'Disasters and transport systems: loss, recovery and competition at the Port of Kobe after the 1995 earthquake', Journal of Transport Geography, Vol. 8, No. 1, pp.53-65.

Cohen, J. and Monaco, K. (2008) 'Ports and highways infrastructure, an analysis of intra- and interstate spillovers', International Regional Science Review, Vol. 31, No. 3, pp.257-274.

Ducruet, C. and Jeong, O. (2005) European Port-City Interface and Its Asian Application, Korea Research Institute for Human Settlements, Gyeonggi-do.

Foster, L., Haltiwanger, J.C. and Krizan, C.J. (2001) 'Aggregate productivity growth. Lessons from microeconomic evidence', in Hulten, C.R., Dean, E.R. and Harpr, M.J. (Ed.): New Development in Productivity Analysis, pp.303-372, University of Chicago Press.

Gallup, J.L., Sachs, J.D. and Mellinger, A.D. (1999) 'Geography and economic development', International Regional Science Review, Vol. 22, No. 2, pp.179-232.

Gleave, M.B. (1997) 'Port activities and the spatial structure of cities: the case of Freetown, Sierra Leone', Journal of Transport Geography, Vol. 5, No. 4, pp.257-275.

Goss, R.O. (1990) 'Economic policies seaports: 1. The economic functions of seaports', Maritime Policy and Management, Vol. 17, No. 3, pp.207-219.

Greene, W.H. (2008) Econometric Analysis, pp.148-167, 180-203, 256-257, Pearson Prentice Hall, New Jersey.

Grobar, L.M. (2008) 'The economic status of areas surrounding major U.S container ports: evidence and policy issues', Growth and Change, Vol. 39, No. 3, pp.497-516.

Harringan, J. and Venables, J.A. (2006) 'Timeliness and agglomeration', Journal of Urban Economics, Vol. 59, No. 2, pp.300-316.

Jeong, H. (2004) 'Development of footwear cluster in Busan', Journal of Korean Academy of Human Resources Management, Vol. 6, pp.287-314.

Jiwittanakulpaisarn, P., Noland, R.B. and Noland, D.J. (2010) 'Causal linkage between highway and sectoral employment', Transportation Research Part A, Vol. 44, No. 4, pp.265-280.

Kim, S., Lim, J. and Lee, J. (2008) 'Evolutionary perspectives on the evolutionary dynamics of the footwear industry in Korea', Journal of the Economic Geographical Society of Korea, Vol. 11, No. 4, pp.509-526.

Kim, J. (2001) A Study on Standard Guidelines Pre-feasibility Study on Port (in Korean), Korea Development Institute, Seoul.

Korea International Trade Association (1991-2011) Korea Trade Statistics [online] http://stat.kita.net (accessed 4 January 2016).

Krafft, J., Lechevalier, S., Quatraro, F. and Storz, C. (2014) 'Emergence and evolution of new industries: the path-dependent dynamics of knowledge creation. An introduction to the special section', Research Policy, Vol. 43, No. 10, pp.1663-1664.

Krugman, P. (1980) 'Scale economies, 'product differentiation, and the pattern of trade', The American Economic Review, Vol. 70, No. 5, pp.950-959.

Kwak, S., Yoo, S. and Chang, J. (2005) 'The role of the maritime industry in the Korean national economy: an input-output analysis’, Marine Policy, Vol. 29, No. 4, pp.371-383.

Lee, S., Song, D. and Ducruet, C. (2008) 'A tale of Asia's world ports: the spatial evolution in global hub port cities', Geoforum, Vol. 39, No. 1, pp.372-385.

$\mathrm{Li}, \mathrm{H}$. and $\mathrm{Li}, \mathrm{Z}$. (2013) 'Road investment and inventory reduction: firm level evidence from China', Journal of Urban Economics, Vol. 76, pp.43-52. 
Limao, N. and Venables, A.J. (2001) 'Infrastructure, geographical disadvantage, transport costs, and trade', World Bank Economic Review, Vol. 15, No. 3, pp.451-479.

MacKellar, L., Worgotter, A. and Worz, J. (2000) 'Economic development problem of landlocked countries', Transition Economic Series, No. 14, Institute for Advanced Studies, Vienna.

Ministry of Land, Transport and Maritime Affairs of Korea (2009) Port in Korea of Korea, p.11, Korea.

Ministry of Oceans and Fisheries of Korea (2015) [online] http://www.spidc.go.kr.10443/com/url/engPAGEURL.do (accessed 9 March 2015).

Notteboom, T.E. and Rodrigue, J. (2005) 'Port regionalization: towards a new phase in port development', Maritime Policy and Management, Vol. 32, No. 3, pp.297-313.

Park, J.S. and Seo, Y. (2016) 'The impact of seaports on the regional economies in South Korea: panel evidence from the augmented Solow model', Transportation Research Part E, Vol. 85, pp.107-119.

Pavcnik, N. (2002) 'Trade liberalization, exit, and productivity improvements: evidence from Chilean plants', The Review of Economic Studies, Vol. 69, No. 1, pp.245-276.

Rodrigue, J. and Notteboom, T.E. (2010) 'Comparative North American and European gateway logistics: the regionalism of freight distribution', Journal of Transport Geography, Vol. 18, No. 4, pp.497-507.

Seo, J.K., Cho, M. and Skelton, T. (2015) 'Dynamic Busan: envisioning a global hub city in Korea', Cities, Vol. 46, pp.26-34.

Shan, J., Yu, M. and Lee, C. (2014) 'An empirical investigation of the seaport's economic impacts: evidence from major ports in China', Transportation Research E, Vol. 69, pp.41-535.

Shim, S. (2004) A Study on General Guidelines Pre-feasibility Study, Korea Development Institute, Korea.

Shin, D. (2004) 'Restructuring the footwear production cluster in Busan, Korea', Journal of KRSA, Vol. 20, No. 1, pp.79-101.

Statistics Korea (1991-2011) Mining and Manufacturing Survey, in Korean, Korea.

Stevens, B.H., Treyz, G.I. and Kindahl, J.K. (1981) 'Conjoining an input-output model and a policy analysis model: a case study of the regional econometric effects of the regional effects of expanding a port facility', Environment and Planning A, Vol. 13, No. 8, pp.1029-1038.

Tong, T., Yu, T., Cho, S., Jensen, K. and Ugarte, D.L.T. (2013) 'Evaluating the spatial spillover effects of transportation infrastructure on agricultural output across the United States', Journal of Transport Geography, Vol. 30, pp.47-55.

UN Comtrade (1991-2011) UN Comtrade Database [online] http://comtrade.un.org/data (accessed 4 January 2016).

UNCTAD (2013) 'Trade indicators and economic resilience', Paper presented at Multi-Year Expert Meeting on Enhancing Economic Environment at all Levels, Geneva, p.15.

World Economic Forum (2010) The Global Competitiveness Report 2009-2010, p.56, Geneva. 